\title{
A Mononuclear and a Mixed-Valence Chain Polymer Arising from Copper(II) Halide Chemistry and the Use of 2,2'-Pyridil
}

\author{
Constantinos J. Milios, ${ }^{1}$ Catherine P. Raptopoulou, ${ }^{2}$ Aris Terzis, ${ }^{2}$ \\ Spyros P. Perlepes, ${ }^{3}$ and Giannis S. Papaefstathiou ${ }^{4}$ \\ ${ }^{1}$ School of Chemistry, The University of Edinburgh, West Mains Road, Edinburgh EH9 3JJ, UK \\ ${ }^{2}$ Institute of Materials Science, National Centre of Scientific Research "Demokritos", 15310 Aghia Paraskevi Attikis, Greece \\ ${ }^{3}$ Department of Chemistry, University of Patras, 26504 Patras, Greece \\ ${ }^{4}$ Laboratory of Inorganic Chemistry, Department of Chemistry, National and Kapodistrian University of Athens, \\ Panepistimiopolis, 15771 Zografou, Greece
}

Received 14 February 2007; Accepted 14 April 2007

Recommended by Jean Pierre Tuchagues

Reactions of 2,2'-pyridil (pyCOCOpy) with $\mathrm{CuCl}_{2} \cdot 2 \mathrm{H}_{2} \mathrm{O}$ and $\mathrm{CuBr}_{2}$ in EtOH yielded the mononuclear complex $\left[\mathrm{Cu}(\text { pyCOOEt })_{2} \mathrm{Cl}_{2}\right] \cdot \mathrm{H}_{2} \mathrm{O}(\mathbf{1})$ and the one-dimensional, mixed-valence complex $\left[\mathrm{Cu}_{2}^{\mathrm{I}} \mathrm{Cu}^{\mathrm{II}}\left(\mathrm{pyCOOEt}_{2} \mathrm{Br}_{4}\right]_{\mathrm{n}}(\mathbf{2})\right.$, respectively. Both complexes crystallize in the triclinic space group $\mathrm{P} \overline{1}$. The lattice constants are $a=8.382(2), b=9.778(2), c=7.814(2)$, $\alpha=101.17(1), \beta=114.55(1), \gamma=94.14(1)^{\circ}$ for 1 and $a=8.738(1), b=9.375(2), c=7.966(1), \alpha=79.09(1), \beta=64.25(1)$, $\gamma=81.78(1)^{\circ}$ for $2.2,2^{\prime}$-pyridil undergoes a metal-assisted alcoholysis and oxidation leading to decomposition and yielding the ethyl picolinate (pyCOOEt) ligand. The autoredox process associated with the reduction of copper(II) to copper(I) in the case of complex 2 is discussed in terms of the increased redox activity of the copper(II) bromide system relative to the copper(II) chloride system.

Copyright (c) 2007 Constantinos J. Milios et al. This is an open access article distributed under the Creative Commons Attribution License, which permits unrestricted use, distribution, and reproduction in any medium, provided the original work is properly cited.

\section{INTRODUCTION}

During the last two decades, we have been pursuing studies $[1,2]$ towards the development of routes and strategies for the synthesis of high-nuclearity complexes of $3 \mathrm{~d}$ metals in moderate oxidation states, since such clusters may display unusual structures and interesting magnetic properties. One of our routes [1] that we have been exploiting takes advantage of the observation that the reactions between metal carboxylates and di-2-pyridyl ketone (pyCOpy, Scheme 1) lead to incomplete replacement of the carboxylate ligands by anionic forms of the ligand and the formation of large polynuclear arrays of metal ions. The structural diversity of the resultant species stems from the ability of the singly and doubly deprotonated anions of the gem-diol form of pyCOpy to adopt a variety of coordination modes, and sometimes two different modes occur in the same complex. This strategy has resulted in the formation of several polynuclear metal complexes with nuclearities ranging from 3 to 26 exhibiting aesthetical appealing structures and interesting magnetic properties [1].
In a next step, our efforts turned towards the use of $2,2^{\prime}$ pyridil (pyCOCOpy, Scheme 1), which presents a chemical similarity with pyCOpy but contains an extra donor group, in order to see how incorporation of this ligand type might affect the structures and physical properties of the products [3]. The reaction "blend" of pyCOCOpy and carboxylate ligands in alcohols produced a series of planar pentanuclear copper(II) complexes with the general formula $\left[\mathrm{Cu}_{5}(\mathrm{OH})_{2}\left\{\mathrm{pyCO}(\mathrm{OR}) \mathrm{CO}(\mathrm{OR}) \mathrm{py}_{2}\left(\mathrm{O}_{2} \mathrm{CMe}\right)_{4}(\mathrm{ROH})_{2}\right](\mathrm{R}=\right.$ Et, n-Pr), where the ligand pyCO $(\mathrm{OR}) \mathrm{CO}(\mathrm{OR}) \mathrm{py}^{2-}$ (see Scheme 1) is a product of the metal-assisted nucleophilic addition of ethanol to the carbonyl groups of pyCOCOpy.

Herein we report our efforts to expand the almost unexplored coordination chemistry of $2,2^{\prime}$-pyridil [3] by incorporating the less basic halides $\left(\mathrm{Cl}^{-}, \mathrm{Br}^{-}\right)$, instead of carboxylates, in the reaction scheme. In the presence of these halides, pyCOCOpy undergoes a metal-promoted alcoholysis and oxidation to yield the pyCOOEt ligand (see Scheme 1). In the case of the bromide, an autoredox process results in the reduction of copper(II) to copper(I) 
<smiles>O=C(c1ccccn1)c1ccccn1</smiles>

pyCOpy<smiles>O=C(C(=O)c1ccccn1)c1ccccn1</smiles>

pyCOCOpy<smiles>[R]OC([O-])(c1ccccn1)C([O-])(O[R])c1ccccn1</smiles>

pyCO(OR)CO(OR)py ${ }^{2-}$<smiles>CCOC(=O)c1ccccn1</smiles>

pyCOOEt<smiles>N#CC(=O)c1ccccn1</smiles>

pic $^{-}$<smiles></smiles>

pyC $(\mathrm{OH})(\mathrm{COO}) \mathrm{py}^{-}$<smiles>O=C(O)C([O-])(c1ccccn1)c1ccccn1</smiles>

$\operatorname{pyC}(\mathrm{COOR})(\mathrm{O}) \mathrm{py}^{-}$

Scheme 1: Ligands discussed in the text.

yielding a mixed-valence $\mathrm{Cu}^{\mathrm{I}} / \mathrm{Cu}^{\mathrm{II}}$ complex, while in the case of the chloride a mononuclear copper(II) complex is obtained.

Autoredox processes-not uncommon in copper halide chemistry-cause reduction of copper(II) to copper(I) often leading to mixed-valence systems [4]. The increased redox activity of the copper(II) bromide system relative to the copper(II) chloride system has been documented [5]. It has been suggested that this process involves the decomposition of $\mathrm{CuBr}_{2}$ to $\mathrm{CuBr}$ and $\mathrm{Br}_{2}$ [6]. Mixed valency is well established in biology [7]. Biological systems have given scientists an opportunity to explore the ways in which mixed valency is used to store and transfer energy, convert light to chemical reactivity in photosynthesis, and in general utilize mixed valency in redox reactions.

\section{EXPERIMENTS}

All manipulations were performed under aerobic conditions using materials and solvents as received. IR spectra were recorded on a Perkin-Elmer PC16 FT-IR spectrometer with samples prepared as $\mathrm{KBr}$ pellets. Far-IR spectra were recorded on a Bruker IFS 113v FT spectrometer with samples prepared as polyethylene pellets. $\mathrm{C}, \mathrm{H}$, and $\mathrm{N}$ elemental analyses were performed with a Carlo Erba EA 108 analyzer:

$$
\left[\mathrm{Cu}(\text { pyCOOEt })_{2} \mathrm{Cl}_{2}\right] \cdot \mathrm{H}_{2} \mathrm{O} \text {. }
$$

A warm solution $\left(50^{\circ} \mathrm{C}\right)$ of $2,2^{\prime}$-pyridil $(0.10 \mathrm{~g}, 0.47 \mathrm{mmol})$ in $\mathrm{EtOH}\left(10 \mathrm{~cm}^{3}\right)$ was added to a warm solution $\left(50^{\circ} \mathrm{C}\right)$ of $\mathrm{CuCl}_{2} \cdot 2 \mathrm{H}_{2} \mathrm{O}(0.08 \mathrm{~g}, 0.47 \mathrm{mmol})$ in EtOH $\left(10 \mathrm{~cm}^{3}\right)$. The resulting green solution was cooled to room temperature and layered with a mixture of $\mathrm{Et}_{2} \mathrm{O} / \mathrm{n}$-hexane $\left(1: 1 \mathrm{v} / \mathrm{v}, 40 \mathrm{~cm}^{3}\right)$. Well-formed, X-ray quality green-blue crystals of 1 appeared within a period of ten days. The crystals were collected by vacuum filtration, washed with EtOH $\left(2 \times 2 \mathrm{~cm}^{3}\right)$ and $\mathrm{Et}_{2} \mathrm{O}$ $\left(2 \times 5 \mathrm{~cm}^{3}\right)$, and dried in air. The yield was ca. $50 \%$ (based on copper). Found \%: C, 42.45; H, 4.62; N, 5.98. Calc \% for $\mathrm{C}_{16} \mathrm{H}_{20} \mathrm{~N}_{2} \mathrm{O}_{5} \mathrm{CuCl}_{2}$ : C, 42.26; H, 4.43; N, 6.16. Selected IR data $\left(\mathrm{KBr}, \mathrm{cm}^{-1}\right): 3562(\mathrm{~m}), 3106(\mathrm{w}), 3070(\mathrm{w}), 3020(\mathrm{w})$, $2986(\mathrm{w}), 2940$ (w), 2908 (w), 1708 (s), 1598 (s), $1572(\mathrm{w})$, $1474(\mathrm{~m}), 1448(\mathrm{w}), 1434(\mathrm{w}), 1402(\mathrm{w}), 1374(\mathrm{~m}), 1332(\mathrm{~s})$, $1300(\mathrm{~m}), 1262(\mathrm{~m}), 1170(\mathrm{~m}), 1114(\mathrm{w}), 1100(\mathrm{~m}), 1054$ $(\mathrm{m}), 1012(\mathrm{~m}), 918(\mathrm{w}), 872(\mathrm{w}) .862(\mathrm{w}), 822(\mathrm{w}), 772(\mathrm{~m})$, $694(\mathrm{~m}), 652(\mathrm{w}), 458(\mathrm{w})$ :

$$
\left[\mathrm{Cu}_{2}^{\mathrm{I}} \mathrm{Cu}^{\mathrm{II}}(\text { pyCOOEt })_{2} \mathrm{Br}_{4}\right]_{\mathrm{n}} \text {. }
$$

A warm solution $\left(50^{\circ} \mathrm{C}\right)$ of $2,2^{\prime}$-pyridil $(0.09 \mathrm{~g}, 0.42 \mathrm{mmol})$ in EtOH $\left(10 \mathrm{~cm}^{3}\right)$ was added to a warm solution $\left(50^{\circ} \mathrm{C}\right)$ of $\mathrm{CuBr}_{2}(0.10 \mathrm{~g}, 0.45 \mathrm{mmol})$ in the same solvent $\left(15 \mathrm{~cm}^{3}\right)$. The resulting brown solution was cooled to room temperature and layered with a mixture of $\mathrm{Et}_{2} \mathrm{O} / \mathrm{n}$-hexane $(1: 1 \mathrm{v} / \mathrm{v}$, $50 \mathrm{~cm}^{3}$ ). Well-formed, X-ray quality brown crystals of 2 appeared within a period of a week. The crystals were collected by vacuum filtration, washed with $\mathrm{EtOH}\left(2 \times 2 \mathrm{~cm}^{3}\right)$ and $\mathrm{Et}_{2} \mathrm{O}\left(2 \times 5 \mathrm{~cm}^{3}\right)$, and dried in air. The yield was ca. $40 \%$ (based on copper). Found \%: C, 23.55; H, 2.12; N, 3.58. Calc $\%$ for $\mathrm{C}_{16} \mathrm{H}_{18} \mathrm{~N}_{2} \mathrm{O}_{4} \mathrm{Cu}_{3} \mathrm{Br}_{4}$ : C, 23.65; H, 2.23; N, 3.45. Selected IR data $\left(\mathrm{KBr}, \mathrm{cm}^{-1}\right)$ : $3054(\mathrm{w}), 2974(\mathrm{w}), 1662$ (m,br), 1596 (s), 1570 (w), 1470 (w), 1438 (w), 1408 (m), $1384(\mathrm{~s})$, $1336(\mathrm{~s}), 1264(\mathrm{~m}), 1180(\mathrm{w}), 1158(\mathrm{w}), 1096(\mathrm{w}), 1054(\mathrm{w})$, $1030(\mathrm{w}), 1004(\mathrm{~m}), 858(\mathrm{w}), 822(\mathrm{w}), 768(\mathrm{~m}), 690(\mathrm{~m}), 658$ $(\mathrm{w}), 456(\mathrm{w})$.

\subsection{X-ray crystallography}

Both data sets were collected at $298 \mathrm{~K}$ using a P2 ${ }_{1}$ Nicolet diffractometer with $\mathrm{Ni}$-filtered $\mathrm{Cu}-K_{\alpha}$ radiation $(\lambda=$ $1.54180 \AA$ ). Data for 2 were corrected for Lorentz, polarization, and absorption effects. Symmetry equivalent data 


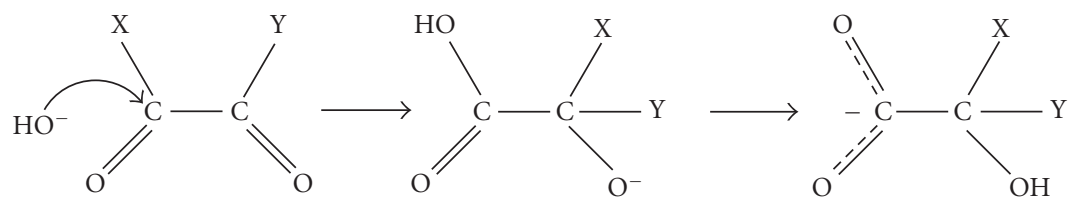

Scheme 2: The $\mathrm{OH}^{-}$-promoted benzilic acid rearrangement.

TABLE 1: Crystal data and structure refinement for $\mathbf{1}$ and $\mathbf{2}$.

\begin{tabular}{lcc}
\hline Empirical formula & $\mathrm{C}_{16} \mathrm{H}_{20} \mathrm{Cl}_{2} \mathrm{CuN}_{2} \mathrm{O}_{5}$ & $\mathrm{C}_{16} \mathrm{H}_{18} \mathrm{Br}_{4} \mathrm{Cu}_{3} \mathrm{~N}_{2} \mathrm{O}_{4}$ \\
Formula weight & 454.78 & 812.58 \\
Crystal size & $0.25 \times 0.30 \times 0.40$ & $0.15 \times 0.25 \times 0.50$ \\
Crystal system & Triclinic & Triclinic \\
Space group & $\mathrm{P} \overline{1}$ & $\mathrm{P} \overline{1}$ \\
$\theta$ range for data & $5.89 \leq \theta \leq 64.96$ & $7.16 \leq \theta \leq 64.97$ \\
collection. & & \\
$a, \AA$ & $8.382(2)$ & $8.738(1)$ \\
$b, \AA$ & $9.778(2)$ & $9.375(2)$ \\
$c, \AA$ & $7.814(1)$ & $7.966(1)$ \\
$\alpha,{ }^{\circ}$ & $101.167(8)$ & $79.093(7)$ \\
$\beta,{ }^{\circ}$ & $114.547(9)$ & $64.251(7)$ \\
$\gamma,{ }^{\circ}$ & $94.141(9)$ & $81.777(8)$ \\
$V, \AA^{3}$ & $563.1(2)$ & $575.7(2)$ \\
$Z$ & 1 & 1 \\
$\rho_{\text {calcd }}$ g cm $^{-3}$ & 1.335 & 2.344 \\
$\mu, \mathrm{mm}^{-1}$ & 3.777 & 11.572 \\
$G O F$ & 1.171 & 1.039 \\
$R 1^{\mathrm{a}}$ & 0.077 & 0.065 \\
$w R 2$ & 0.213 & 0.176 \\
\hline
\end{tabular}

${ }^{\mathrm{a}} I>2 \sigma(I)$.

of 1 and 2 were averaged with $R_{\text {int }}=0.0124$ and 0.0261 , respectively, to give 1902 and 1916 independent reflections from a total 2055 and 2050 collected. Both structures were solved by direct methods and were refined by full-matrix least-squares on $\mathrm{F}^{2}$, using 1902 (1) and 1916 (2) reflections, and refining 143 and 159 parameters, respectively. All nonhydrogen atoms were refined anisotropically, except Ow1 and Ow2 for 1 which were refined isotropically. All hydrogen atoms bonded to carbon atoms were located by difference maps and their positions were refined isotropically. There were no significant residual peaks in either electron density map. Details of the data collection and refinement are given in Table 1.

\section{RESULTS AND DISCUSSION}

\subsection{Synthesis}

Reactions of pyCOCOpy with $\mathrm{CuCl}_{2} \cdot 2 \mathrm{H}_{2} \mathrm{O}$ or $\mathrm{CuBr}_{2}$ in EtOH resulted in the mononuclear $\mathrm{Cu}^{\mathrm{II}}$ complex 1 and a mixed-valence $\mathrm{Cu}^{\mathrm{I}} / \mathrm{Cu}^{\mathrm{II}}$ coordination polymer 2 , respectively. The ligand found in these two complexes, pyCOOEt, is a product of alcoholysis (nucleophilic addition of $\mathrm{EtOH}$ to the carbonyl group) and oxidation of the pyCOCOpy ligand, followed by its decomposition. In this metal-assisted reaction it might not be necessary for the carbonyl atom(s) to be coordinated to the metal centre. The induced polarization from the pyridyl nitrogen atoms' coordination might be sufficient [8].

$\mathrm{Cu}^{\mathrm{II}} /$ pyCOCOpy reaction systems were synthetically investigated in the past. A similar reaction of pyCOCOpy with $\mathrm{CuCl}_{2} \cdot 2 \mathrm{H}_{2} \mathrm{O}$ or $\mathrm{Cu}\left(\mathrm{ClO}_{4}\right)_{2} \cdot 6 \mathrm{H}_{2} \mathrm{O}$ in $\mathrm{MeOH}$ has resulted in trans- $\left[\mathrm{Cu}(\mathrm{pic})_{2}\right] \cdot 2 \mathrm{H}_{2} \mathrm{O}\left(\mathrm{pic}^{-}=\right.$picolinate, Scheme 1) $[9,10]$. The picolinate ligand found in this complex is the product of the metal ion-promoted nucleophilic addition of $\mathrm{OH}^{-}$(from $\mathrm{H}_{2} \mathrm{O}$ in the solvent) to the carbonyl group and oxidation of pyCOCOpy. trans- $\left[\mathrm{Cu}(\mathrm{pic})_{2}\right]$ has also been isolated as a byproduct from the reaction of $\left[\mathrm{Cu}_{2}\left(\mathrm{O}_{2} \mathrm{CMe}\right)_{4}\left(\mathrm{H}_{2} \mathrm{O}\right)_{2}\right]$ or $\mathrm{Cu}\left(\mathrm{O}_{2} \mathrm{CPh}\right)_{2} \cdot$ EtOH with pyCO$\mathrm{COpy}$ in $\mathrm{n}-\mathrm{PrOH}$ or $\mathrm{EtOH}$ at room temperature, respectively [3]; these reactions gave the unusual pentanuclear complexes mentioned in the introduction. It has also been reported that trans- $\left[\mathrm{Cu}(\text { pic })_{2}\right]$ and/or trans- $\left[\mathrm{Cu}(\text { pic })_{2}\right] \cdot 2 \mathrm{H}_{2} \mathrm{O}$ are the major products from the reaction of $\left[\mathrm{Cu}_{2}\left(\mathrm{O}_{2} \mathrm{CMe}\right)_{4}\left(\mathrm{H}_{2} \mathrm{O}\right)_{2}\right]$ or $\mathrm{Cu}\left(\mathrm{O}_{2} \mathrm{CPh}\right)_{2} \cdot \mathrm{EtOH}$ with pyCOCOpy in $\mathrm{MeOH}$ under reflux [3]. Thus, the $\mathrm{Cu}^{\mathrm{II}}$-promoted transformation of pyCOCOpy to pyCOOEt, observed in $\mathbf{1}$ and $\mathbf{2}$, is novel.

The coordination chemistry of pyCOCOpy with other metal ions has also been investigated. It appears that the reaction conditions as well as the nature of the metal ion are crucial in such reactions. The reactions of $\mathrm{M}\left(\mathrm{ClO}_{4}\right)_{2}$. $6 \mathrm{H}_{2} \mathrm{O}\left(\mathrm{M}=\mathrm{Co}^{\mathrm{II}}\right.$ or $\left.\mathrm{Ni}^{\mathrm{II}}\right)$ with pyCOCOpy in $\mathrm{MeOH}$ under reflux resulted in complexes $\left[\mathrm{Co}^{\mathrm{III}}\left\{\mathrm{pyC}(\mathrm{OH})(\mathrm{COO}) \mathrm{py}_{2}\right]\right.$ $\left(\mathrm{ClO}_{4}\right) \cdot \mathrm{MeOH}$ and $\left[\mathrm{Ni}\left\{\mathrm{pyC}(\mathrm{OH})(\mathrm{COO}) \mathrm{py}_{2}\right] \cdot 2 \mathrm{H}_{2} \mathrm{O}\right.$, respectively [10]; pyC $(\mathrm{OH})(\mathrm{COO}) \mathrm{py}^{-}$is the anion of pyridilic acid (see Scheme 1), which is a product of the nucleophilic addition of $\mathrm{OH}^{-}$to one O-bonded carbonyl group of pyCOCOpy, followed by a benzilic acid-type rearrangement. The reaction pathway for the classical base-induced benzilic acid-type rearrangement is represented in Scheme 2 $[8,11]$. The crucial step in the overall process is the migration of the group $\mathrm{X}$ from the carbon atom attacked by $\mathrm{OH}^{-}$to the adjacent carbon atom, whereby the carbon center initially under attack becomes a carboxylate. It has been demonstrated that the benzilic acid rearrangement can be promoted by $3 \mathrm{~d}$-metal ions $[8,11]$. Recently [11] Abrahams et al. studied the $\mathrm{Ca}^{\mathrm{II}} /$ pyCOCOpy reaction system in basic alcoholic solutions. Solutions containing $\mathrm{Ca}\left(\mathrm{NO}_{3}\right)_{2} \cdot 4 \mathrm{H}_{2} \mathrm{O}$, pyCOCOpy and $\mathrm{Et}_{3} \mathrm{~N}$ in either $\mathrm{MeOH}$ or $\mathrm{EtOH}$ in a sealed tube at $\sim 90^{\circ} \mathrm{C}$ gave the cubane complexes $\left[\mathrm{Ca}_{4}\{\mathrm{pyC}(\mathrm{COOR})(\mathrm{O}) \mathrm{py}\}_{4}\left(\mathrm{NO}_{3}\right)_{4}\right]$, where $\mathrm{R}=\mathrm{Me}$ or 


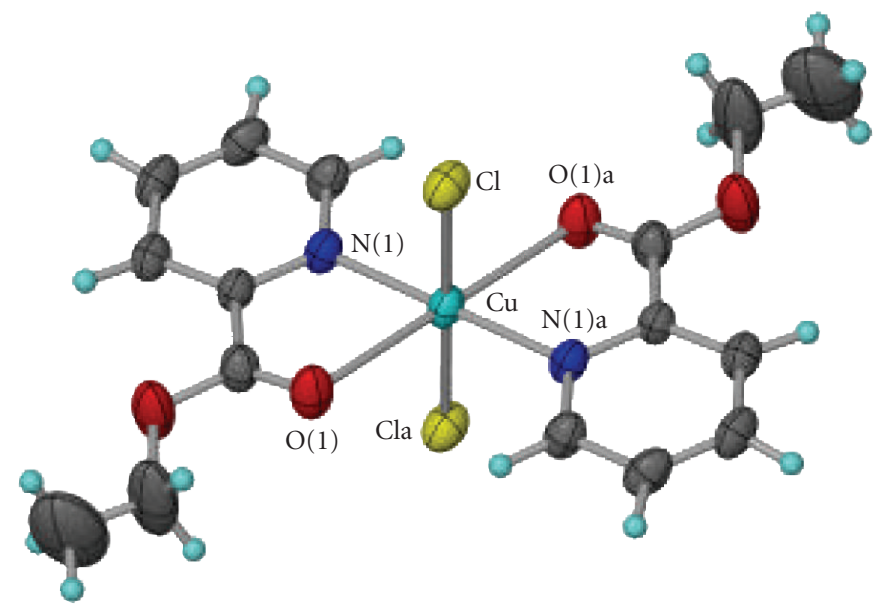

FIgURE 1: The molecular structure of $\mathbf{1}$.

Et. The reaction proceeds by a similar benzilic acid rearrangement where esterification of the carboxylic acid has occurred to give the coordinated anion pyC(COOR)(O) py ${ }^{-}$ (see Scheme 1).

When pyCOCOpy was treated with $\mathrm{CuBr}_{2}$, an autoredox process took place that led to the partial reduction of copper(II) to copper(I) and the isolation of the mixed-valence $\mathrm{Cu}^{\mathrm{I}} / \mathrm{Cu}^{\mathrm{II}}$ polymeric complex 2 . This reduction does not take place when $\mathrm{CuCl}_{2} \cdot 2 \mathrm{H}_{2} \mathrm{O}$ is used instead of $\mathrm{CuBr}_{2}$. This experimental observation is in accordance with literature data which indicate that the redox activity of the copper(II) bromide system is increased relative to the copper(II) chloride system [4-6].

\subsection{IR spectra}

The IR spectra of the two complexes are similar but not identical. The $v(\mathrm{C}=\mathrm{O})$ and the $v(\mathrm{C}-\mathrm{O})$ vibrational modes in the spectra of the free ligand (pyCOOEt) occur at 1729 and $1254 \mathrm{~cm}^{-1}$ [12], respectively; these bands shift to lower $\left[1708 \mathrm{~cm}^{-1}(1), 1662 \mathrm{~cm}^{-1}(2)\right]$ and higher $\left[1262 \mathrm{~cm}^{-1}(1)\right.$, $1264 \mathrm{~cm}^{-1}$ (2)] wavenumbers, respectively, in the spectra of the two complexes as a result of the coordination of the carbonyl-type ester oxygen. The significantly lower wavenumber of $v(\mathrm{C}=\mathrm{O})$ in the spectrum of 2 , as compared to the $v(\mathrm{C}=\mathrm{O})$ in the spectrum of $\mathbf{1}$, is due to the weak interaction of the carbonyl oxygen of the pyCOOEt ligand with one $\mathrm{Cu}^{\mathrm{I}}$ ion in the crystal structure of $\mathbf{2}$ (vide infra); this interaction gives a pseudobridging character in the carbonyl-type ester oxygen. The $v(\mathrm{C} \cdots \mathrm{C})$ and $\nu(\mathrm{C} \cdots \mathrm{N})$ modes of the pyridyl ring occur at 1592, 1573, 1465 and $1432 \mathrm{~cm}^{-1}$ in the spectrum of the free ligand [12]; these modes shift to higher wavenumbers in the spectrum of the two complexes confirming that the pyridyl nitrogen acts as a donor.

The strong band at $271 \mathrm{~cm}^{-1}$ in the far-IR spectrum of $\mathbf{1}$ is assigned to the $\nu(\mathrm{Cu}-\mathrm{Cl})_{\mathrm{t}}$ mode [13]; this band is absent in the spectrum of 2 , as expected. The 201, 190, and $175 \mathrm{~cm}^{-1}$
TABLE 2: Selected dond lengths $(\AA)$ and angles $\left(^{\circ}\right)$ for $\mathbf{1}$.

\begin{tabular}{lclc}
\hline $\mathrm{Cu}-\mathrm{N}(1)$ & $1.992(3)$ & $\mathrm{Cl}-\mathrm{Cu}-\mathrm{Cla}$ & $180.0(1)$ \\
$\mathrm{Cu}-\mathrm{Cl}$ & $2.307(1)$ & $\mathrm{N}(1)-\mathrm{Cu}-\mathrm{O}(1)$ & $75.1(1)$ \\
$\mathrm{Cu}-\mathrm{O}(1)$ & $2.438(4)$ & $\mathrm{Cl}-\mathrm{Cu}-\mathrm{O}(1)$ & $91.4(1)$ \\
$\mathrm{N}(1)-\mathrm{Cu}-\mathrm{N}(1) \mathrm{a}$ & $180.0(1)$ & $\mathrm{N}(1)-\mathrm{Cu}-\mathrm{O}(1) \mathrm{a}$ & $105.0(1)$ \\
$\mathrm{N}(1)-\mathrm{Cu}-\mathrm{Cl}$ & $90.4(1)$ & $\mathrm{Cl}-\mathrm{Cu}-\mathrm{O}(1) \mathrm{a}$ & $88.6(1)$ \\
$\mathrm{N}(1)-\mathrm{Cu}-\mathrm{Cla}$ & $89.6(1)$ & $\mathrm{O}(1)-\mathrm{Cu}-\mathrm{O}(1) \mathrm{a}$ & $180.0(1)$ \\
\hline
\end{tabular}

Symmetry transformation used to generate equivalent atoms: a $-x$, $-y,-z$.

bands in the spectrum of 2 are associated with the bridging $\mathrm{Cu}^{\mathrm{II}}-\mathrm{Br}$ and $\mathrm{Cu}^{\mathrm{I}}-\mathrm{Br}$ stretches [13].

\subsection{Description of structures}

The molecular structure of $\mathbf{1}$ is shown in Figure 1, and selected bond lengths and angles are listed in Table 2. The structure consists of a neutral $\left[\mathrm{Cu}(\text { pyCOOEt })_{2} \mathrm{Cl}_{2}\right]$ molecule and one water molecule which is split over four positions with $25 \%$ occupancy. The $\mathrm{Cu}^{\mathrm{II}}$ atom is situated on a crystallographic centre of inversion and has an axially elongated distorted octahedral environment with two pyridyl nitrogen atoms and two $\mathrm{Cl}^{-}$on the equatorial plane, and the two carbonyl-type oxygen atoms at the axial positions $[\mathrm{Cu}-\mathrm{O}(1)$ 2.438(4) A]. Two pyCOOEt ligands chelate to the metal centre through the pyridyl nitrogen atom and the carbonyl-type oxygen atom. The distortion of the axially elongated octahedron is due to the small bite angle $\mathrm{N}(1)-\mathrm{Cu}-\mathrm{O}(1)$ of the $\mathrm{O}, \mathrm{N}$-chelating ligand which is $75.1(1)^{\circ}$.

The molecular structure of 2 is shown in Figure 2, and selected bond lengths and angles appear in Table 3. The structure consists of $\left[\mathrm{Cu}_{2}^{\mathrm{I}} \mathrm{Cu}^{\mathrm{II}}(\mathrm{pyCOOEt})_{2} \mathrm{Br}_{4}\right]_{\mathrm{n}}$ chains that run parallel to the $b$ axis. Each chain is composed of alternating $\mathrm{Cu}^{\mathrm{II}}$ (pyCOOEt) ${ }_{2} \mathrm{Br}_{2}$ and $\mathrm{Cu}_{2}^{\mathrm{I}} \mathrm{Br}_{2}$ subunits. The $\mathrm{Cu}^{\mathrm{II}}$ atom $[\mathrm{Cu}(2)]$ is situated on a crystallographic centre of inversion and has an axially elongated distorted octahedral 


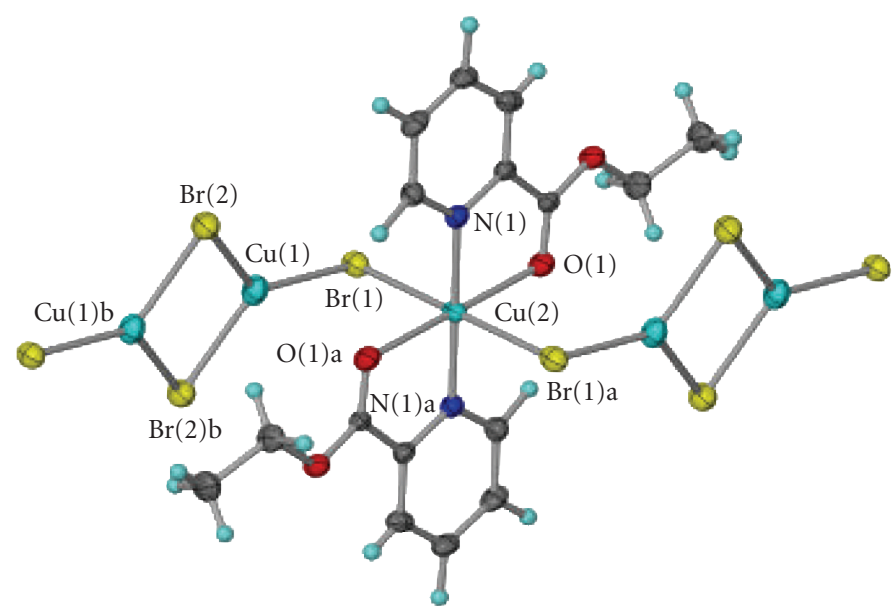

FIgURe 2: Part of the one-dimensional coordination polymer 2.

TABLe 3: Selected bond lengths $(\AA)$ and angles $\left({ }^{\circ}\right)$ for 2 .

\begin{tabular}{lrrr}
\hline $\mathrm{Cu}(1)-\mathrm{Br}(1)$ & $2.337(1)$ & $\mathrm{Cu}(1)-\mathrm{Br}(2)-\mathrm{Cu}(1) \mathrm{b}$ & $67.1(1)$ \\
$\mathrm{Cu}(1)-\mathrm{Br}(2)$ & $2.387(1)$ & $\mathrm{N}(1)$ (a) $-\mathrm{Cu}(2)-\mathrm{N}(1)$ & $180.0(1)$ \\
$\mathrm{Cu}(1)-\mathrm{Br}(2) \mathrm{b}$ & $2.443(1)$ & $\mathrm{N}(1)-\mathrm{Cu}(2)-\mathrm{O}(1)$ & $79.9(2)$ \\
$\mathrm{Cu}(2)-\mathrm{N}(1)$ & $1.960(5)$ & $\mathrm{N}(1)-\mathrm{Cu}(2)-\mathrm{O}(1) \mathrm{a}$ & $100.1(2)$ \\
$\mathrm{Cu}(2)-\mathrm{O}(1)$ & $2.201(5)$ & $\mathrm{O}(1)-\mathrm{Cu}(2)-\mathrm{O}(1) \mathrm{a}$ & $180.0(1)$ \\
$\mathrm{Cu}(2)-\mathrm{Br}(1)$ & $2.664(1)$ & $\mathrm{N}(1)-\mathrm{Cu}(2)-\mathrm{Br}(1)$ & $87.4(1)$ \\
$\mathrm{Br}(1)-\mathrm{Cu}(1)-\mathrm{Br}(2)$ & $129.8(1)$ & $\mathrm{O}(1)-\mathrm{Cu}(2)-\mathrm{Br}(1)$ & $87.4(1)$ \\
$\mathrm{Br}(1)-\mathrm{Cu}(1)-\mathrm{Br}(2) \mathrm{b}$ & $117.1(1)$ & $\mathrm{N}(1)-\mathrm{Cu}(2)-\mathrm{Br}(1) \mathrm{a}$ & $92.6(1)$ \\
$\mathrm{Br}(2)-\mathrm{Cu}(1)-\mathrm{Br}(2) \mathrm{b}$ & $112.9(1)$ & $\mathrm{O}(1)-\mathrm{Cu}(2)-\mathrm{Br}(1) \mathrm{a}$ & $92.6(1)$ \\
$\mathrm{Cu}(1)-\mathrm{Br}(1)-\mathrm{Cu}(2)$ & $92.5(1)$ & $\mathrm{Br}(1)-\mathrm{Cu}(2)-\mathrm{Br}(1) \mathrm{a}$ & $180.0(1)$ \\
\hline
\end{tabular}

Symmetry transformations used to generate equivalent atoms: a 1-x, 1-y, $z$; b 1-x, 2-y, $z$.

environment with two pyridyl nitrogen atoms and two carbonyl-type ester oxygen atoms on the equatorial plane, and two $\mathrm{Br}^{-}$atoms at the axial positions $[\mathrm{Cu}(2)-\mathrm{Br}(1)$ 2.664(1) $\AA$ ]. Contrary to 1 , the distortion of the axial elongated octahedron around the $\mathrm{Cu}^{\mathrm{II}}$ atom is less pronounced due to the larger bite angle $\mathrm{N}(1)-\mathrm{Cu}(2)-\mathrm{O}(1)$ of the $\mathrm{O}, \mathrm{N}$ chelating ligand which is $79.9(2)^{\circ}$. The two pyCOOEt ligands chelate to the metal centre through the pyridyl nitrogen atom and the carbonyl-type oxygen atom.

The $\mathrm{Cu}_{2}^{\mathrm{I}} \mathrm{Br}_{2}$ subunit forms a four-membered ring that lies around a crystallographic centre of inversion. The $\mathrm{Cu}^{\mathrm{I}} \cdots \mathrm{Cu}^{\mathrm{I}}[\mathrm{Cu}(1) \cdots \mathrm{Cu}(1) \mathrm{b}]$ distance is $2.669 \AA$ and the $\mathrm{Cu}^{\mathrm{I}}-\mathrm{Br}-\mathrm{Cu}^{\mathrm{I}}[\mathrm{Cu}(1)-\mathrm{Br}(2)-\mathrm{Cu}(1) \mathrm{b}]$ angle is $67.1(1)^{\circ}$ (b: $1-x, 2-y,-z)$. Each $\mathrm{Cu}^{\mathrm{II}}$ (pyCOOEt) ${ }_{2} \mathrm{Br}_{2}$ moiety bridges two $\mathrm{Cu}_{2}^{\mathrm{I}} \mathrm{Br}_{2}$ subunits through its axial $\mathrm{Br}^{-}$ligands. The $\mathrm{Cu}^{\mathrm{II}} \cdot \mathrm{Cu}^{\mathrm{I}}[\mathrm{Cu}(2) \cdots \mathrm{Cu}(1)]$ distance is $3.618 \AA$ and the $\mathrm{Cu}^{\mathrm{II}}-\mathrm{Br}-\mathrm{Cu}^{\mathrm{I}}[\mathrm{Cu}(2)-\mathrm{Br}(1)-\mathrm{Cu}(1)]$ angle is $92.5(1)^{\circ}$. Therefore, each $\mathrm{Cu}^{\mathrm{I}}$ is surrounded by three $\mathrm{Br}^{-}$atoms in a distorted trigonal planar arrangement. The three $\mathrm{Br}-\mathrm{Cu}-\mathrm{Br}$ angles are $112.9(1)^{\circ}[\mathrm{Br}(2)-\mathrm{Cu}(1)-\mathrm{Br}(2) \mathrm{b}], 117.1(1)^{\circ}$ $[\mathrm{Br}(1)-\mathrm{Cu}(1)-\mathrm{Br}(2) \mathrm{b}]$, and $129.9(1)^{\circ}[\mathrm{Br}(1)-\mathrm{Cu}(1)-\mathrm{Br}(2)]$, while the three $\mathrm{Cu}^{\mathrm{I}}-\mathrm{Br}$ distances are 2.337(1) $\left.\AA \mathrm{Cu}(1)-\mathrm{Br}(1)\right]$, 2.387(1) $\AA[\mathrm{Cu}(1)-\mathrm{Br}(2)]$, and 2.443(1) $\AA[\mathrm{Cu}(1)-\mathrm{Br}(2) \mathrm{b}]$.
In addition to the three $\mathrm{Br}^{-}$atoms, there is a weak contact between the carbonyl-type oxygen atom of the pyCOOEt ligand and the $\mathrm{Cu}^{\mathrm{I}}$ atom. The carbonyl atom is situated above the $\mathrm{Cu}^{\mathrm{I}} \mathrm{Br}_{3}$ plane and the almost perpendicular to the trigonal plane $\mathrm{Cu}^{\mathrm{I}}$. . . O distance is $2.898 \AA$.

The $\mathrm{Cu}^{\mathrm{I}}$ and $\mathrm{Cu}^{\mathrm{II}}$ sites have distinctly different geometries which are typical for their oxidation states. Therefore, 2 can be described as a class I complex according to the Robin-Day classification scheme for the mixed-valence compounds [7]. This scheme divides mixed-valence compounds into three broad classes. In class I the metals of different valence have distinctly different geometries which are typical for each oxidation state. Class III mixed-valence species are strongly delocalized systems in which the symmetry and ligand environment of the two metal sites are identical; it is possible to further divide class III into III-A and III-B, depending whether or not discrete polynuclear groupings of indistinguishable metal ions can be distinguished in the crystal. Class II compounds represent an intermediate classification in which delocalization does take place, but the two types of site remain distinguishable.

Complexes $\mathbf{1}$ and $\mathbf{2}$ are the second and third, respectively, structurally characterized metal complexes of pyCOOEt. The 
first one was the $1 \mathrm{D}$ polymer $\left[\mathrm{HgCl}_{2}(\text { pyCOOEt })\right]_{n}$ containing six-coordinate $\mathrm{Hg}^{\mathrm{II}}$ atoms, ( $\left.\mathrm{N}, \mathrm{O}_{\text {carbonyl }}\right)$-chelating pyCOOEt molecules and exclusively $\mu-\mathrm{Cl}^{-}$ligands [14].

\section{Material}

Crystallographic data have been deposited with the CCDC (12 Union Road, Cambridge, CB2 1EZ, UK) and are available on request quoting the deposition numbers CCDC 637117 and 637118 for 1 and 2 , respectively (fax: +441233-336033; e-mail: deposit@ccdc.cam.ac.uk or http://www .ccdc.cam.ac.uk).

\section{CONCLUSIONS}

The reactions of pyCOCOpy with $\mathrm{CuCl}_{2} \cdot 2 \mathrm{HO}$ and $\mathrm{CuBr}_{2}$ in warm EtOH resulted in a mononuclear copper(II) complex and a mixed-valence polymeric complex, respectively. The 2,2'-pyridil molecule underwent a metal ion-assisted nucleophilic addition of EtOH and oxidation to produce pyCOOEt, which was incorporated as a ligand in both complexes. Although both reactions took place under the same conditions (same solvent, concentration, temperature, ligand), only in the case of copper(II) bromide we managed to isolate a mixed-valence complex. The isolation of a mixedvalence complex when copper(II) bromide was the starting material confirms the increased redox activity of copper(II) bromide relative to copper(II) chloride. The results presented here support our belief that the $\mathrm{Br}^{-} /$pyCOCOpy ligand "blends" may be effective generators of interesting structural types in the chemistry of other redox-active transition metals.

\section{ACKNOWLEDGMENTS}

The authors thank the European Social Fund (ESF), the Operational Program for Educational and Vocational Training II (EPEAEK II), and particularly the Program PYTHAGORAS I (Grant b. 365.037) for funding the above work.

\section{REFERENCES}

[1] G. S. Papaefstathiou and S. P. Perlepes, "Families of polynuclear manganese, cobalt, nickel and copper complexes stabilized by various forms of di-2-pyridyl ketone," Comments on Inorganic Chemistry, vol. 23, no. 4, pp. 249-274, 2002.

[2] C. J. Milios, T. C. Stamatatos, and S. P. Perlepes, "The coordination chemistry of pyridyl oximes," Polyhedron, vol. 25, no. 1, pp. 134-194, 2006, (Polyhedron Report).

[3] G. S. Papaefstathiou, C. P. Raptopoulou, A. Tsohos, A. Terzis, E. G. Bakalbassis, and S. P. Perlepes, "Alcoholysis of 2,2' pyridil, $\left(2-\mathrm{C}_{5} \mathrm{H}_{4} \mathrm{~N}\right) \mathrm{C}(\mathrm{O}) \mathrm{C}(\mathrm{O})\left(2-\mathrm{C}_{5} \mathrm{H}_{4} \mathrm{~N}\right)$, in the presence of copper(II): a family of planar pentanuclear copper(II) complexes stabilized by $\left[\left(2-\mathrm{C}_{5} \mathrm{H}_{4} \mathrm{~N}\right) \mathrm{C}(\mathrm{O})(\mathrm{OR}) \mathrm{C}(\mathrm{O})(\mathrm{OR})(2-\right.$ $\left.\left.\mathrm{C}_{5} \mathrm{H}_{4} \mathrm{~N}\right)\right]^{2-}$ and carboxylate ligands," Inorganic Chemistry, vol. 39, no. 20, pp. 4658-4662, 2000.

[4] R. D. Willett, G. Pon, and C. Nagy, "Crystal chemistry of the 4, 4' -dimethyl-2, 2' bipyridine/copper bromide system," Inorganic Chemistry, vol. 40, no. 17, pp. 4342-4352, 2001.

[5] R. D. Willett, "Bromination of the 3-chloroanilinium cation: structure of a novel two-dimensional copper(I) bromide lat- tice prepared via in-situ redox processes," Inorganic Chemistry, vol. 40, no. 5, pp. 966-971, 2001.

[6] R. D. Willett and K. Halvorson, "Structures of catalytically related species involving copper(II) halides. VI. Tetrakis(3aminopyridinium) decabromodicuprate(I)dicuprate(II)," Acta Crystallographica, vol. C44, pp. 2068-2071, 1988.

[7] J. P. Fackler Jr., "Mixed valence compounds," in Encyclopedia of Inorganic Chemistry, R. B. King, Ed., vol. 5, pp. 2270-2281, John Wiley \& Sons, Chichester, UK, 1994.

[8] E. W. Constable, Metals and Ligand Reactivity, VCH, Weinheim, Germany, 2nd edition, 1996.

[9] M. G. Barandika, Z. E. Serna, M. K. Urtiaga, J. I. R. De Larramendi, M. I. Arriortua, and R. Cortés, "Crystal structure and magnetic properties of two metal-picolinate systems obtained from degradation of bis(2-pyridylketone) through reaction with $\mathrm{Mn}(\mathrm{II})$ and $\mathrm{Cu}(\mathrm{II}), "$ Polyhedron, vol. 18, no. 8-9, pp. 1311-1316, 1999.

[10] M. Du, X.-H. Bu, M. Shionoya, and M. Shiro, "Metal assisted rearrangement of 2,2' -pyridil with $\mathrm{M}\left(\mathrm{CIO}_{4}\right)_{2} \cdot 6 \mathrm{H}_{2} \mathrm{O}(\mathrm{M}=$ $\mathrm{Co}^{\mathrm{II}}, \mathrm{Ni}^{\mathrm{II}}$ and $\left.\mathrm{Cu}^{\mathrm{II}}\right)$ : syntheses, characterization and crystal structures," Journal of Molecular Structure, vol. 607, no. 2-3, pp. 155-161, 2002.

[11] B. F. Abrahams, T. A. Hudson, and R. Robson, "In situ synthesis of trisubstituted methanol ligands and their potential as one-pot generators of cubane-like metal complexes," Chemistry, vol. 12, no. 27, pp. 7095-7102, 2006.

[12] R. W. Hay and C. R. Clark, "Transition metal complexes of 2-carbethoxypyridine (ethyl picolinate)," Transition Metal Chemistry, vol. 4, pp. 28-31, 1979.

[13] K. Nakamoto, Infrared and Raman Spectra of Inorganic and Coordination Compounds, John Wiley \& Sons, New York, NY, USA, 4th edition, 1986.

[14] A. Álvarez-Larena, W. Clegg, L. Cucurull-Sánchez, et al., "Mercury(II) halide adducts of esters of 2-pyridinecarboxylic acid. Crystal structures and structural variations within the series $\left[\mathrm{HgCl}_{2}\left(\mathrm{C}_{5} \mathrm{H}_{4} \mathrm{NCOOR}\right)\right], \mathrm{R}=\mathrm{Me}, \mathrm{Et}, \mathrm{Pr}^{\mathrm{n}}, \mathrm{Pr}^{\mathrm{i}}$, ' Inorganica Chimica Acta, vol. 266, no. 1, pp. 81-90, 1997. 


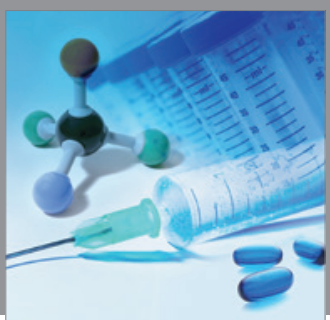

International Journal of

Medicinal Chemistry

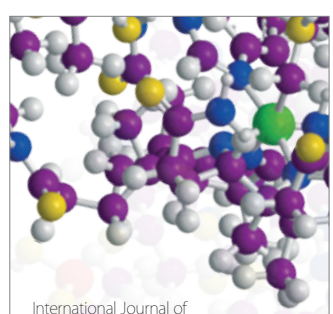

Carbohydrate Chemistry

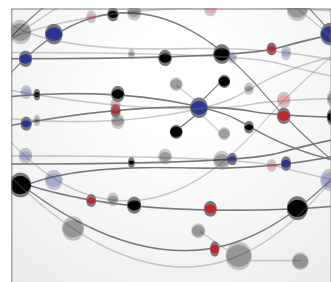

The Scientific World Journal
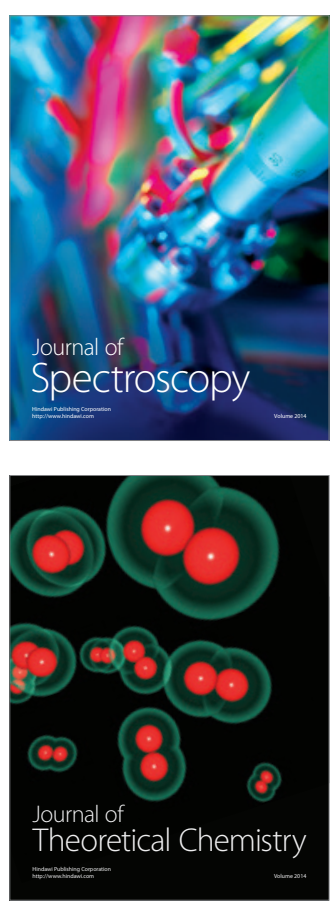
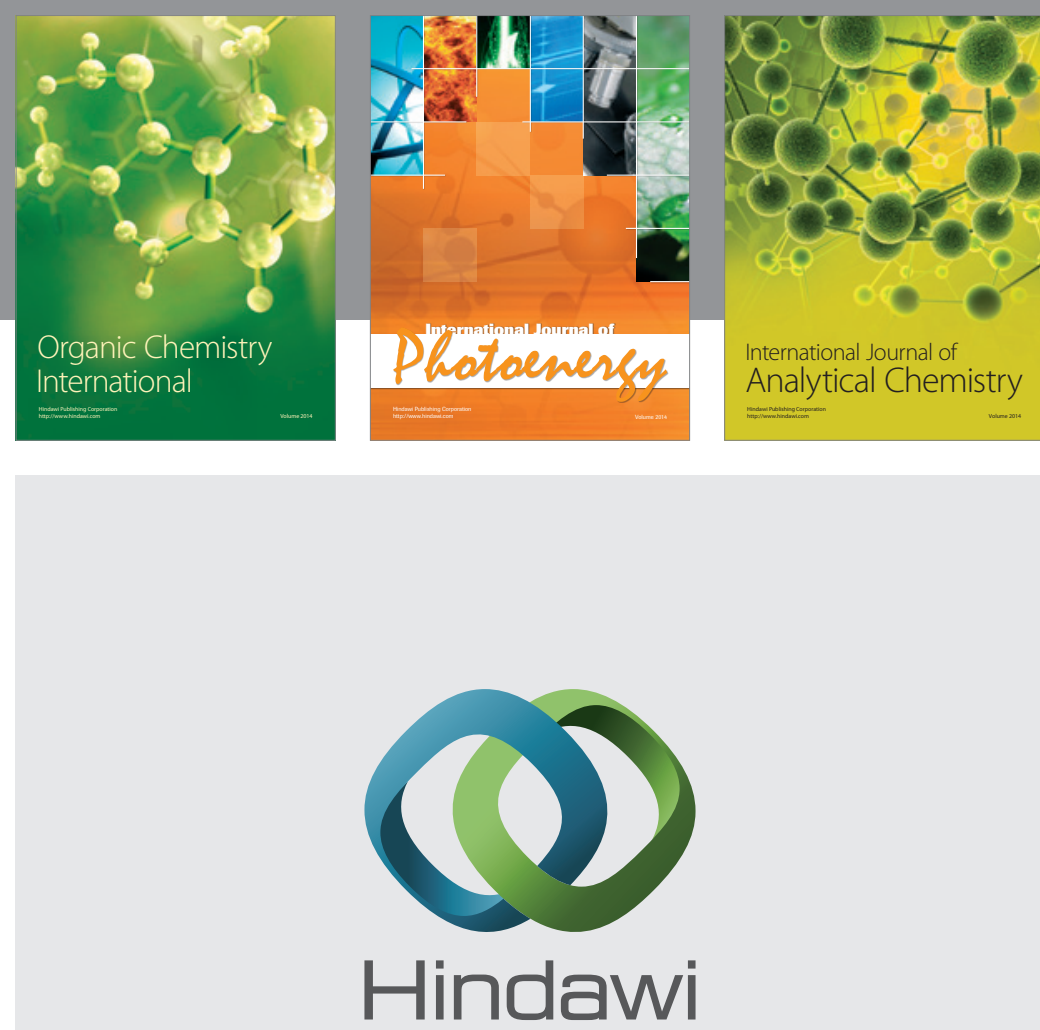

Submit your manuscripts at

http://www.hindawi.com
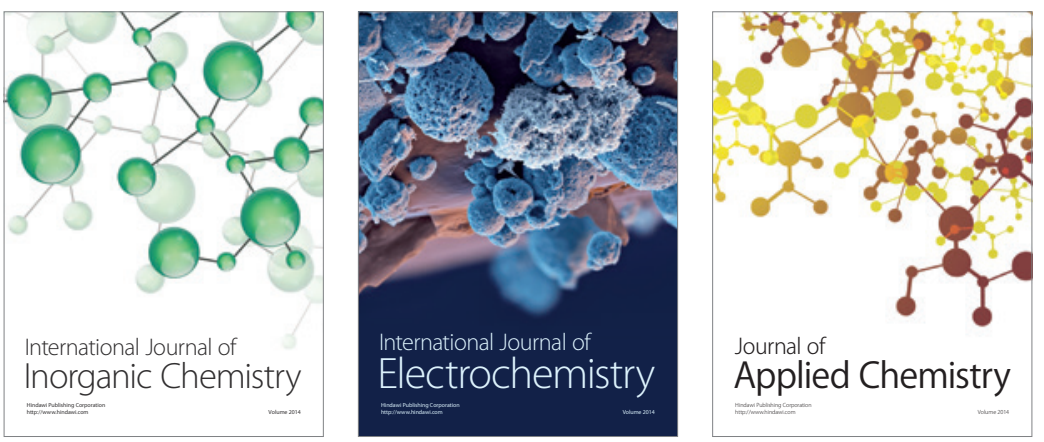

Journal of

Applied Chemistry
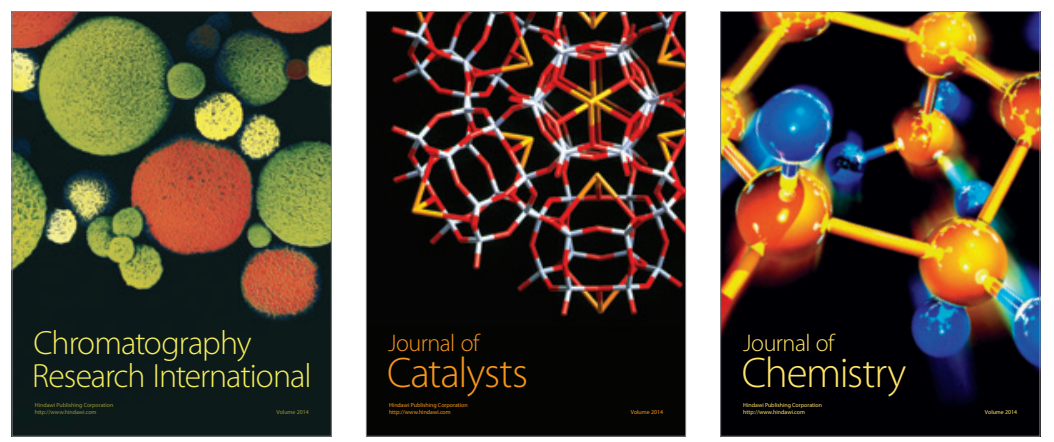
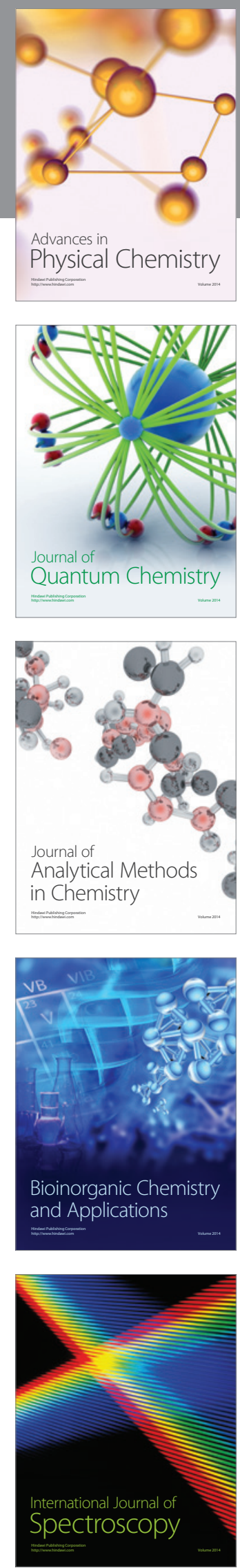